\title{
Chlamydia trachomatis genovar distribution in clinical urogenital specimens from Tunisian patients: high prevalence of $C$. trachomatis genovar $E$ and mixed infections
}

\author{
Houda Gharsallah', Olfa Frikha-Gargouri ${ }^{1}{ }^{1},{ }^{1}$, Hanen Sellami ${ }^{1}$, Fatma Besbes $^{1}$, Abir Znazen ${ }^{1}$ \\ and Adnene Hammami $i^{1,3^{*}}$
}

\begin{abstract}
Background: This epidemiological study was carried out in Sfax (south of Tunisia) and focused on genital Chlamydia trachomatis (C. trachomatis) genovar distribution.

Methods: One hundred and thirty seven genital samples from 4067 patients (4.2\%) attending the Habib Bourguiba University hospital of Sfax over 12 years (from 2000 to 2011) were found to be C. trachomatis PCR positive by the Cobas Amplicor system. These samples were genotyped by an in house reverse hybridization method.

Results: One hundred and eight (78.8\%) samples contained only one genovar and 29 (21.2\%) samples contained two or three genovars. Genovar E was the most prevalent (70.8\%) single genovar and it was detected in $90.6 \%$ of all the cases. Genovars J, C and L1-L3 were not detected in our samples whereas ocular genovars A and B were in 5 cases. All the five cases were mixed infections. Men had more mixed infections than women $(p=0.02)$ and were more frequently infected by genovars $F$ and $K(p<0.05)$. No associations between current infection, infertility and the genovar distribution were observed. Patients coinfected with Neisseria gonorrhoeae were also significantly more frequently infected with mixed genovars $(p=0.04)$.
\end{abstract}

Conclusions: In conclusion, we have reported a high prevalence of genovar $E$ and of mixed infections in our study population. Such data could have implications for the control and vaccine development of C. trachomatis in Tunisia.

Keywords: Chlamydia trachomatis, Genotyping, Reverse hybridization method

\section{Background}

Chlamydia trachomatis (C. trachomatis) infections are the most common sexually transmitted bacterial infections in the world. The World Health Organization estimated that 92 million new cases of Chlamydia infections occurred globally in 2001 [1]. Genital infection with $C$. trachomatis is associated with a wide spectrum of diseases if the infection was not treated. In men, urogenital C. trachomatis infection causes urethritis

\footnotetext{
* Correspondence: adnene.hammami@rns.tn

'Department of Microbiology and research laboratory "Microorganismes et Pathologie Humaine", Habib Bourguiba university hospital, medical school of Sfax, University of Sfax, Sfax, Tunisia

${ }^{3}$ Mailing address: Laboratory of microbiology, University school of medecine of Sfax, Avenue Magida Boulila, 3027 Sfax, Tunisia

Full list of author information is available at the end of the article
}

that may lead to complications such as epididymitis in rare cases. In women, clinical manifestations show cervicitis that can ascend in the upper genital tract and cause pelvic inflammatory disease and infertility. The diseases caused by $C$. trachomatis also include trachoma, the world's leading cause of preventable blindness [2] as well as lymphogranuloma venereum (LGV), a severe systemic infection [3].

C. trachomatis strains are conventionally divided into 19 genovars based on the heterogeneity of the ompA gene sequence. The different genovars of C. trachomatis are associated with the various clinical manifestations caused by this bacterium. Genovars A to $\mathrm{C}$ are predominantly associated with trachoma and were rarely detected in urogenital diseases. Genovars D to $\mathrm{K}$ are

\section{Biomed Central}


associated with urogenital diseases, and genovars L1 to L3 are associated with the LGV. C. trachomatis genovars are also classified into 3 distinct groups on the basis of their amino acid sequence homology: the $\mathrm{B}$ group ( $\mathrm{B}, \mathrm{Ba}, \mathrm{D}, \mathrm{Da}, \mathrm{E}, \mathrm{L} 1, \mathrm{~L} 2 \mathrm{a}$ and $\mathrm{L} 2 \mathrm{~b})$, the $\mathrm{C}$ group (A, $\mathrm{C}, \mathrm{H}, \mathrm{I}, \mathrm{Ia}, \mathrm{J}, \mathrm{Ja}, \mathrm{K}$ and $\mathrm{L} 3$ ) and the intermediate group (F and G) [4].

In the previous studies performed in Tunisia, C. trachomatis was reported in $15 \%$ among men with urethritis (data not published), in 59\% among patients with arthritis [5], in $43.3 \%$ among infertile men with leukocytospermia [6] and in 73\% of prostitutes [7]. Thus, C. trachomatis infection seems to be prevalent in our country, but no information about $C$. trachomatis genovar distribution in our population has been described so far.

Thus, we undertook this study to genotype C. trachomatis strains circulating in Tunisia using our in house reverse hybridization method. We also aimed to assess the relationship between gender, age, clinical and microbiological factors and C. trachomatis genovars. Such data might give insights into the $C$. trachomatis strains circulating in Tunisia and help develop strategies of sexually transmitted infections control.

\section{Methods}

\section{Clinical C. trachomatis samples}

One hundred and seventy two urethral and/or endocervical swabs positive for $C$. trachomatis using Cobas Amplicor (Roche molecular system, Mannheim Germany), were collected from Tunisian patients at the Habib Bourguiba University hospital in Sfax between February 2000 and June 2011. Specimens were collected using cytobrush, and the contents were transferred immediately into a tube containing $1 \mathrm{ml} 2$-SP transport medium. Specimens were kept at $-80^{\circ} \mathrm{C}$ until testing.

These specimens were also tested for Neisseria gonorrhoeae (N. gonorrhoeae) nucleic acids with the Amplicor CT/NG polymerase chain reaction (PCR). DNA extraction from $200 \mu \mathrm{l} 2$-SP transport medium and PCR procedures were performed according to the manufacturer's instructions.

All subjects provided verbal informed consent, and the study protocol was approved by our ethics committee (Association d'Enregistrement et de Lutte Contre le Cancer du Sud Tunisien).

\section{Extraction of genomic DNA}

Genomic DNA from clinical swabs was extracted from $200 \mu \mathrm{l}$ of urethral and endocervical swabs using the QIAmp DNA Mini kit (QIAGEN GmbH, Hilden, Germany) according to the manufacturer's instructions. The DNA was then eluted in $50 \mu \mathrm{l}$ of the elution buffer and stored at $-20^{\circ} \mathrm{C}$. The extracted DNA was tested for human $\beta$-globin gene to check for PCR inhibitors in the samples. Primers ß-GPCO (5'-ACACAACTGTGTT CACTAGC- $3^{\prime}$ ), and $ß$-GPCPO (5'-GAAACCCAA GAGTCTTCTCT- 3'), were used to amplify a 209 bp fragment of the human $ß$-globin gene.

\section{PCR amplification of the VS1-VS2 fragment}

Urethral and endocervical DNA positive by Cobas Amplicor C. trachomatis test were selected for the ompA amplification and genotyping. A semi nested PCR was used for the amplification using the NLO (BiotinATGAAAAAACTCTTGAAATCG) [8] and C214 (Biotin-TCTTCGAYTTTAGGTTTAGATTGA) [9] primers for the first PCR and the NLO and CT4 (Biotin-GATT GAGCGTATTGGAAAGAAGC) [10] primers for the semi nested PCR. The reaction mixture consisted of $3 \mu \mathrm{l}$ of extracted DNA, $0.5 \mu \mathrm{M}$ of each primer, $0.2 \mathrm{mM}$ dNTP; $1 \mathrm{U}$ of the flexi Taq DNA polymerase (Promega, Madison WI, USA). PCRs were performed using the GeneAmp PCR System 9600 thermocycler under the following conditions: 2 min of denaturation at $95^{\circ} \mathrm{C}$, followed by 35 cycles of amplification at $95^{\circ} \mathrm{C}$ for $45 \mathrm{sec}, 45^{\circ} \mathrm{C}$ for 45 sec, and $72^{\circ} \mathrm{C}$ for $45 \mathrm{sec}$. The ompA PCR products were visualized after electrophoresis in $1 \%$ agarose gels by ethidium bromide staining.

\section{The reverse hybridization method}

An in house reverse hybridization method for C. trachomatis genotyping was first developed in our laboratory and was validated using $14 \mathrm{C}$. trachomatis reference strains [11]. Then this method was used for the specific detection of $C$. trachomatis genotypes. Briefly, the nylon membrane was spotted with probes hybridizing specifically to genovars A to L3 at specific positions. Reverse hybridization probes were then attached to the membrane by baking at $120^{\circ} \mathrm{C}$ for $30 \mathrm{~min}$. Membranes were prehybridized for $30 \mathrm{~min}$ at $37^{\circ} \mathrm{C}$ and then hybridization took place over the night at $37^{\circ} \mathrm{C}$ with shaking. The biotinylated duplex DNA-probe was revealed after incubation with the alkaline phosphatase enzyme for one hour at $37^{\circ} \mathrm{C}$ and then with its substrate: the Western Blue stabilized substrate (Promega, Madison WI, USA) for $30 \mathrm{~min}$ at room temperature and in the dark. Washing was performed between each of the incubation steps.

\section{Statistical analysis}

Data were analyzed using SPSS version 13.0. Differences were statistically compared by the Chi-square test or the Fisher's exact test when sample sizes were small. $p<0.05$ was considered as significant.

\section{Results}

During twelve years, urethral and endocervical swabs from 4067 Tunisian patients were collected in the Habib Bourguiba University hospital in Sfax between February 
2000 and June 2011 and were subjected to the Cobas Amplicor CT/NG PCR testing. One hundred and seventy two samples (4.2\%) were found to be PCR positive and only 138 were available for C. trachomatis genotyping. Of these 138 samples, 84 (60.9\%) were collected from men and 54 (39.1\%) from women. Data on age were obtained from 115 individuals. The median age was 30 years and the $95 \%$ confidence interval was [28.85-31.45]. Thirty two individuals (23.9\%) were under 25 years. Thirty seven individuals $(27 \%)$ were consulted for infertility (5 men and 32 women), 96 (70\%) for the current infection (76 men and 20 women) and one man consulted for both infertility and the current infection $(0.7 \%)$. Data were not available for the remaining 3 patients (2.2\%). Mixed infections with N. gonorrhoeae were detected in 18 cases (13.1\%) (Table 1 ).

All the 138 samples $C$. trachomatis Cobas PCR positive were successfully screened by the $\beta$-globin PCR test and no inhibition was detected. One hundred and thirty seven samples were then amplified by our semi nested PCR, generating a sensitivity of $99 \%$. These amplicons were used for the detection of $C$. trachomatis genotypes by the reverse hybridization method. Genovar distribution results of the 137 samples are shown in Table 1. A heterogeneous distribution of the $137 \mathrm{C}$. trachomatis genovars was observed. All genovars belonging to the $\mathrm{D}-\mathrm{K}$ urogenital group were detected except the genovar J. One hundred and eight samples (78.8\%) were infected with a single genovar. The remaining 29 samples (21.2\%) showed mixed infections. Genovar $E$ was the most prevalent $(70.8 \%)$ single infection. In single and mixed infections together, genovar $\mathrm{E}$ was detected in $90.6 \%$ of cases (124/137). The most prevalent mixed infection was observed to be genovars $\mathrm{E}$ and $\mathrm{F}$, and $\mathrm{E}$ and $\mathrm{H}$. Genovar $\mathrm{B}$ was detected in mixed infection with genovar $\mathrm{E}$ in two cases and with genovars $\mathrm{D}$ and $\mathrm{H}$ in one case. Genovar A was detected in mixed infections with genovar $\mathrm{E}$ in one case and with genovars $\mathrm{E}$ and $\mathrm{F}$ in one case. Genovar $\mathrm{C}$ and LGV genovars were not detected in our urogenital samples. The genovar distribution was also investigated according to the year of collection of samples (Additional file 1: Table S1). Generally, all single and mixed genotypes were distributed all over the 12 years.

The relationships between gender, age, current C. trachomatis infection, infertility, $N$. gonorrhoeae infection data and $C$. trachomatis genotypes or group results were examined (Table 2). No statistical differences were observed for the distribution of $C$. trachomatis genotypes between men and women $(p<0.05)$. However, significantly more men had mixed infections $(p=0.02)$ than women. Genovars F and $\mathrm{K}$ were observed more frequently in men than in women $(p<0.05)$ too. In fact, $10.7 \%$ and $3.7 \%$ of men and women, respectively, were infected with genovar $\mathrm{F}$ and $8.3 \%$ and $1.8 \%$ respectively with genovar K. No association was observed between age, current infection, infertility and the genovar distribution. Patients infected with $N$. gonorrhoeae were also significantly more frequently infected by mixed infection $(p=0.04)$, and by genovars other than $\mathrm{E}$ alone $(p=0.03)$ (Table 2).

\section{Discussion}

Many studies have reported the epidemiology of C. trachomatis infection throughout the world. The prevalence of C. trachomatis infections varies from $2 \%$ to $5.6 \%$ in selected and unselected populations [12]. In line with previous studies, the prevalence of $C$. trachomatis infection in our city of Sfax was found to be $4.2 \%$. To our knowledge, $C$. trachomatis genovar distribution has not been reported before in our country. C. trachomatis genotyping was investigated in all urogenital samples collected in Sfax (Tunisia) found to be Cobas amplicor PCR positive since 2000. Ninety nine percent (137/138) of our samples were successfully amplified using our semi nested PCR. This sensitivity is high when compared with those reported in other studies ranging from 44 to 99\% [10,13-15].

The reverse hybridization used in our study is simple and fast. It requires low technology to be performed. It is powerful in the diagnosis of mixed infection and did not show any cross reactivity between reference strains.

In our study, genotype $\mathrm{E}$ was the most prevalent being detected in $70.2 \%$ of single infections. All the other genotypes were detected at percentages ranging from 0.7 to $2.2 \%$. When considering single and mixed infections, genovar $\mathrm{E}$ was detected in $92.6 \%$ of the cases followed by genovar $\mathrm{F}$ that was detected in $10.3 \%$ of the cases. The detection of genovar E was remarkably high in our study but was in line with that of Gita et al., [13] performed in New Delhi (India) reporting the detection of only genovar $\mathrm{E}$ in 22 specimens positive for C. trachomatis by PCR-RFLP. Their high percentage was explained by the small number of specimen processed which was not so in our case. According to the literature, genovars D, E, F and G were reported to be the most prevalent genovars worldwide [8,9,16-21]. Differences in the relative proportions of these genovars in different geographical areas were reported. For example, in Cambodia, genovar D (22.2\%) was the most prevalent followed by genovar F (18.5\%) [22]. In Australia, the most common genovar was E (41\%) followed by genovar F (26\%) [23]. In Sweden, the most common genovar was E (47\%) followed by genovar F (17\%) [15]. Differences in genotype prevalence were found in different study populations. In Thailand, genovar $\mathrm{F}$ was the most prevalent genotype (60\%) among non sex workers, but decreased to $29 \%$ among sex workers [24]. The high detection rate 
Table 1 Genovar types according to patient characteristics

\begin{tabular}{|c|c|c|c|c|c|c|c|c|c|c|c|c|c|}
\hline \multirow{2}{*}{$\begin{array}{l}\text { Genovar } \\
\text { Gender }\end{array}$} & \multirow[t]{2}{*}{$\begin{array}{c}\text { Total } \\
\mathrm{N}=137 \\
(\%)\end{array}$} & \multicolumn{2}{|c|}{$\begin{array}{c}\text { Total } \\
N=137 \\
(\%)\end{array}$} & \multirow[t]{2}{*}{$p$ value } & \multicolumn{2}{|c|}{$\begin{array}{l}\text { Current infection * } \\
\qquad N=96(\%)\end{array}$} & \multirow[t]{2}{*}{$p$ value } & \multicolumn{2}{|c|}{$\begin{array}{l}\text { Infertility * } \\
\mathrm{N}=37 \text { (\%) }\end{array}$} & \multirow[t]{2}{*}{$p$ value } & \multicolumn{2}{|c|}{$\begin{array}{l}\text { NG coinfection } \\
N=18(\%)\end{array}$} & \multirow[t]{2}{*}{$p$ value } \\
\hline & & $\begin{array}{l}\text { Men } \\
\mathrm{N}=84(\%)\end{array}$ & $\begin{array}{l}\text { Women } \\
N=53(\%)\end{array}$ & & $\begin{array}{l}\text { Men } \\
76(57.1)\end{array}$ & $\begin{array}{l}\text { Women } \\
20(15)\end{array}$ & & $\begin{array}{l}\text { Men } \\
5(3.6)\end{array}$ & $\begin{array}{l}\text { Women } \\
32(24)\end{array}$ & & $\begin{array}{l}\text { Men } \\
16(11.7)\end{array}$ & $\begin{array}{l}\text { Women } \\
2(1.5)\end{array}$ & \\
\hline Single & $108(78.8)$ & $61(72.6)$ & 47 (88.7) & 0.03 & $54(40.6)$ & 18 (13.5) & 0.14 & $5(3.6)$ & $28(21)$ & 1.00 & $9(8.0)$ & $2(1.5)$ & 0.49 \\
\hline D & $2(1.5)$ & $0(0)$ & $2(3.8)$ & 0.14 & $0(0)$ & $2(1.5)$ & 0.04 & $0(0)$ & $0(0)$ & $\mathrm{Nd}$ & $0(0)$ & $0(0)$ & $\mathrm{Nd}$ \\
\hline E & $97(70.8)$ & $55(65.5)$ & $42(79.2)$ & 0.12 & 49 (36.8) & $14(10.5)$ & 0.79 & $4(3)$ & $27(20.3)$ & 1.00 & $7(6.5)$ & $2(1.5)$ & 0.47 \\
\hline$F$ & $4(2.9)$ & $4(4.8)$ & $0(0)$ & 0.16 & $3(2.2)$ & $0(0)$ & 1.00 & $1(0.7)$ & $0(0)$ & 0.14 & $1(0.7)$ & 0 & 1.00 \\
\hline G & $3(2.2)$ & $0(0)$ & $3(5.7)$ & 0.06 & $0(0)$ & $2(1.5)$ & 0.04 & $0(0)$ & $1(0.7)$ & 1.00 & $0(0)$ & $0(0)$ & $\mathrm{Nd}$ \\
\hline H & $1(0.7)$ & $1(1.2)$ & $0(0)$ & 1.00 & $1(0.7)$ & $0(0)$ & 1.00 & $0(0)$ & $0(0)$ & $\mathrm{Nd}$ & $0(0)$ & $0(0)$ & $\mathrm{Nd}$ \\
\hline K & $1(0.7)$ & $1(1.2)$ & $0(0)$ & 1.00 & $1(0.7)$ & $0(0)$ & 1.00 & $0(0)$ & $0(0)$ & $\mathrm{Nd}$ & $1(0.7)$ & $0(0)$ & 1.00 \\
\hline Multiple & $29(21.2)$ & $23(27.4)$ & $6(11.3)$ & 0.03 & $22(16.1)$ & $2(1.5)$ & 0.14 & $0(0)$ & $4(3)$ & 1.00 & $7(5.1)$ & $0(0)$ & 0.49 \\
\hline$A+E$ & $1(0.7)$ & $1(1.2)$ & $0(0)$ & 1.00 & $1(0.7)$ & $0(0)$ & 1.00 & $0(0)$ & $0(0)$ & $\mathrm{Nd}$ & $0(0)$ & $0(0)$ & $\mathrm{Nd}$ \\
\hline$B+E$ & $2(1.5)$ & $0(0)$ & $2(3.8)$ & 0.15 & $0(0)$ & $1(0.7)$ & 0.21 & $0(0)$ & $1(0.7)$ & 1.00 & $0(0)$ & $0(0)$ & $\mathrm{Nd}$ \\
\hline$D+F$ & $1(0.7)$ & $1(1.2)$ & $0(0)$ & 1.00 & $1(0.7)$ & $0(0)$ & 1.00 & $0(0)$ & $0(0)$ & $\mathrm{Nd}$ & $0(0)$ & $0(0)$ & $\mathrm{Nd}$ \\
\hline$E+F$ & $5(3.6)$ & $4(4.8)$ & $1(1.9)$ & 0.65 & $4(3)$ & $0(0)$ & 0.58 & $0(0)$ & $1(0.7)$ & 1.00 & $0(0)$ & $0(0)$ & $\mathrm{Nd}$ \\
\hline$E+G$ & $4(2.9)$ & $4(4.8)$ & $0(0)$ & 0.16 & $4(3)$ & $0(0)$ & 0.58 & $0(0)$ & $0(0)$ & $\mathrm{Nd}$ & $2(1.5)$ & $0(0)$ & 1.00 \\
\hline$E+H$ & $5(3.6)$ & $4(4.8)$ & $1(1.9)$ & 0.65 & $4(3)$ & $0(0)$ & 0.58 & $0(0)$ & $1(0.7)$ & 1.00 & $2(1.5)$ & $0(0)$ & 1.00 \\
\hline$E+K$ & $3(2.2)$ & $3(3.6)$ & $0(0)$ & 0.28 & $3(2.2)$ & $0(0)$ & 1.00 & $0(0)$ & $0(0)$ & $\mathrm{Nd}$ & $0(0)$ & $0(0)$ & $\mathrm{Nd}$ \\
\hline$E+I$ & $1(0.7)$ & $1(1.2)$ & $0(0)$ & 1.00 & $0(0)$ & $0(0)$ & $\mathrm{Nd}$ & $0(0)$ & $0(0)$ & $\mathrm{Nd}$ & $1(0.7)$ & $0(0)$ & 1.00 \\
\hline$A+E+F$ & $1(0.7)$ & $0(0)$ & $1(1.9)$ & 0.39 & $0(0)$ & $0(0)$ & $\mathrm{Nd}$ & $0(0)$ & $1(0.7)$ & 1.00 & $0(0)$ & $0(0)$ & $\mathrm{Nd}$ \\
\hline$B+D+H$ & $1(0.7)$ & $1(1.2)$ & $0(0)$ & 1.00 & $1(0.7)$ & $0(0)$ & 1.00 & $0(0)$ & $0(0)$ & $\mathrm{Nd}$ & $1(0.7)$ & $0(0)$ & 1.00 \\
\hline$E+F+H$ & $1(0.7)$ & $1(1.2)$ & $0(0)$ & 1.00 & $1(0.7)$ & $0(0)$ & 1.00 & $0(0)$ & $0(0)$ & $\mathrm{Nd}$ & $0(0)$ & $0(0)$ & $\mathrm{Nd}$ \\
\hline $\mathrm{E}+\mathrm{H}+\mathrm{K}$ & $4(2.9)$ & $3(3.6)$ & 1 (1.9) & 1.00 & $3(2.2)$ & $1(0.7)$ & 1.00 & $0(0)$ & $0(0)$ & $\mathrm{Nd}$ & $1(0.7)$ & $0(0)$ & 1.00 \\
\hline
\end{tabular}

Statistically significan

* The status of infection data was not available for 3 patients. The remaining patient, presenting both current infection and infertility, was discarded from the analysis. Nd: Not determined. 
Table 2 Factors associated with $C$. trachomatis genotype

\begin{tabular}{|c|c|c|c|c|c|c|c|}
\hline & & \multicolumn{6}{|c|}{ Genotype } \\
\hline & & $\begin{array}{l}\text { Single } \\
\mathrm{N}(\%)\end{array}$ & $\begin{array}{l}\text { Mixed } \\
\mathrm{N}(\%) \\
\end{array}$ & $\begin{array}{l}\text { E single } \\
N(\%)\end{array}$ & $\begin{array}{l}\text { E associated } \\
\mathrm{N}(\%)\end{array}$ & $\begin{array}{l}\text { E single } \\
\mathrm{N}(\%)\end{array}$ & $\begin{array}{l}\text { Other genotypes } \\
\mathrm{N}(\%)\end{array}$ \\
\hline \multirow[t]{2}{*}{ Gender } & Men (84) & $61(56.5)$ & $23(79.3)$ & $55(56.7)$ & $21(77.8)$ & $55(56.7)$ & $29(72.5)$ \\
\hline & Women (53) & $47(43.5)$ & $6(20.7)$ & $42(43.3)$ & $6(22.2)$ & $42(43.3)$ & $11(27.5)$ \\
\hline$p$ & & 0.02 & & 0.04 & & NS & \\
\hline \multirow[t]{2}{*}{ Age * } & $<=25(32)$ & $22(24.4)$ & $10(40)$ & $20(24.4)$ & $9(39.1)$ & $20(24.4)$ & $12(36.4)$ \\
\hline & $>25$ (83) & 68 (75.6) & $15(60)$ & $62(75.6)$ & $14(60.9)$ & $62(75.6)$ & $21(63.6)$ \\
\hline$p$ & & NS & & NS & & NS & \\
\hline Infertility ₹ & Presence (37) & $33(24.8)$ & $4(30)$ & $31(23.3)$ & $4(30)$ & $31(23.3)$ & $6(4.5)$ \\
\hline$p$ & & NS & & NS & & NS & \\
\hline Current infection $\neq$ & Presence (96) & $72(54.1)$ & $24(18)$ & $63(47.3)$ & $17(12.8)$ & $63(47.3)$ & $33(24.8)$ \\
\hline$p$ & & NS & & NS & & NS & \\
\hline NG coinfection & Presence (18) & $11(10.2)$ & $7(24.1)$ & $9(9.3)$ & $6(22.2)$ & $9(9.3)$ & $9(22.5)$ \\
\hline$p$ & & 0.04 & & NS & & 0.03 & \\
\hline
\end{tabular}

Statistically significance is marked in bold.

* The age data were available for only 115 patients.

₹The status of infection was not available only for 3 patients. One patient, presenting both current infection and infertility, was discarded from the analysis.

of genovars D, E, F, and G could be related to a longer persistence time of their infections than the other genovars in the genital tract [25].

The high prevalence of genovar E in our study could be explained by a specific immune status of Tunisian patients and by distinctive characteristics of some genotype E strains in our country. Such strains could not be distinguished by our reverse hybridization method. Thus, the application of new typing schemes based on more discriminative method such as multilocus sequence typing or multiple loci variable number of tandem repeats analysis might provide a better understanding of our high prevalence of $C$. trachomatis genovar E. An interesting issue would be to further examine whether all or most of the genovar $E$ in our patients were of the same strain or not. Furthermore, an assessment of in vitro studies of infectivity and cytotoxicity of our local strains in urogenital cell lines may also help to explain the high prevalence of genovar $E$ in our population. Jones et al., [26] suggested that genovar E can outcompete other genovars for nutrients and growth factors leading to a rapid expansion of genovar E when compared to the other genovars.

Mixed infections were detected in our study in 21.1\% of the cases. This percentage seems to be high as most of mixed infections in the literature occur at a percentage not exceeding 15\% [19,27-30]. Mixed infections may result from two separate episodes of infection and the lack of cross protection between genotypes [14]. In our study, single genovars were rarely detected except for genovar $\mathrm{E}$. Genovars $\mathrm{H}$ and $\mathrm{K}$ were detected once in single infections but were detected at high frequencies in mixed infections (11 and 7 times, respectively). These genovars are probably relatively low grade pathogens which could only persist in the presence of other genovars [31].

Trachoma genovars A and B were also detected in 5 patients (3.6\%). All of them were observed in mixed infections. This could not be due to cross reactivity since our technique was well studied with a mixture of reference strains. Also, these genovars were involved in urogenital infections [32-37].

The genovar detection in our study was similar among men and women in line with previous studies suggesting that specific serotypes do not preferentially infect one gender $[23,38]$. However, the occurrence of mixed infections is significantly higher among men than women. Furthermore, a statistically significant difference was found for the occurrence of genovars $\mathrm{F}$ and $\mathrm{K}$ which were observed more frequently in men than in women. Men are probably sexually active with more than one partner leading to the occurrence of mixed infections and infection with another genovar than E. No statistically significant difference in distribution of genotypes and age was found such a result is in a total agreement with other studies [39].

In our study, no association was found between C. trachomatis genotype $\mathrm{E}$ and the patient's infection status (current symptomatic infection and infertility). According to the literature, genovar $\mathrm{E}$ was reported at high frequencies in symptomatic adults [40] as well as in asymptomatic adults $[16,18,19]$. C. trachomatis genovar $E$ was also found in our study to be the most prevalent genovar. In infertile patients from Mexico, C. trachomatis genovar $\mathrm{F}$ was the most prevalent genovar (54\%) followed by genovars E, G, K and LGV (9\%) [41]. 
Patients with $N$. gonorrhoeae infection were significantly more frequently infected by mixed genovars and by genovars other than the single genovar E (Table 2). According to the literature, little is known about $N$. gonorrhoeae coinfection and its association with C. trachomatis genovars. Papadogeorgakis et al., [36] reported a significantly higher proportion of $N$. gonorrhoeae coinfections among patients with urethritis with genovariant Ja. No other associations were reported except for the significant association of $N$. gonorrhoeae coinfection with genovar D [42].

Yet, we could mention a few limitations of our study. First, the smaller sample size of infected patients could affect the relationship between $C$. trachomatis genotypes and clinical manifestations. Second, supplementary information about behavioral characteristics would be useful to explain the difference in genotype distribution among men and women. In addition, the reverse hybridization method used in this study could not detect new genovars and recombinant clinical strains. These could lead to cross hybridizations [11]. The presence of trachoma genotypes and the high frequency of mixed infections have to be confirmed by cloning and complete ompA gene sequencing.

\section{Conclusion}

In conclusion, the present study is the first description of C. trachomatis genovar distribution in Tunisia. C. trachomatis genotype $\mathrm{E}$ infection rate was found to be considerably much higher than other reports in the world. We have also detected a high frequency of mixed infections. This genotype distribution is unique and further studies focused on specific groups are needed to assess whether this figure is specific to Tunisia only. The data obtained in this study could have implications for the control and vaccine development of C. trachomatis in Tunisia.

\section{Additional file}

Additional file 1: Table S1. The prevalence of C. trachomatis in

Tunisian patients.

\section{Competing interests}

The authors declare that they have no competing interests.

\section{Authors' contributions}

HG carried out all the studies, analyzed the data and drafted the manuscript. OFG helped with the analysis, discussion of the data and correction of the manuscript. FB and HS helped with the analysis and discussion of the data. AZ helped with the discussion of the data. AH participated in the study design and helped to draft the manuscript. All authors have read and approved the final manuscript.

\section{Acknowledgments}

This work is part of a doctoral thesis by Houda GHARSALLAH. We would like to thank the "Ministry of Higher Education and Scientific Research, Tunisia» for its financial support.

\section{Author details}

'Department of Microbiology and research laboratory "Microorganismes et Pathologie Humaine", Habib Bourguiba university hospital, medical school of Sfax, University of Sfax, Sfax, Tunisia. ${ }^{2}$ Biopesticides Team, LPAP, Sfax Biotechnology Centre, University of Sfax, Sfax, Tunisia. ${ }^{3}$ Mailing address: Laboratory of microbiology, University school of medecine of Sfax, Avenue Magida Boulila, 3027 Sfax, Tunisia.

Received: 25 March 2012 Accepted: 7 November 2012

Published: 30 November 2012

\section{References}

1. WHO (World Health Organization): Global Prevalence and Incidence of selected Curable Sexually Transmitted Infections: overview and estimates. Geneva, Switzerland: WHO/ HIV_AIDS/2001.02; 10-14.

2. Kasi PM, Gilani Al, Ahmad K, Janjua NZ: Blinding trachoma: a disease of poverty. PLoS Med 2004, 1(2):e44.

3. Mabey D, Peeling RW: Lymphogranuloma venereum. Sex Transm Infect 2002, 78(2):90-92.

4. Yuan Y, Zang YX, Watkins NG, Caldwell HD: Nucleotide and deduced amino acid sequences for the four variable domains of the major outer membrane proteins of the 15 Chlamydia trachomatis serovars. Infect Immun 1989, 57(4):1040-1049.

5. Siala M, Gdoura R, Younes M, Fourati H, Cheour I, Meddeb N, Bargaoui N, Baklouti S, Sellami S, Rihl M, Hammami A: Detection and frequency of Chlamydia trachomatis DNA in synovial samples from Tunisian patients with reactive arthritis and undifferentiated oligoarthritis. FEMS Immunol Med Microbiol 2009, 55(2):178-186.

6. Gdoura R, Kchaou W, Ammar-Keskes L, Chakroun N, Sellemi A, Znazen A, Rebai T, Hammami A: Assessment of Chlamydia trachomatis, Ureaplasma urealyticum, Ureaplasma parvum, Mycoplasma hominis, and Mycoplasma genitalium in Semen and First Void Urine Specimens of Asymptomatic Male Partners of Infertile Couples. J Androl 2008, 29:198-206.

7. Znazen A, Frikha-Gargouri O, Berrajah L, Bellalouna S, Hakim H, Gueddana N, Hammami: A Sexually transmitted infections among female sex workers in Tunisia: high prevalence of Chlamydia trachomatis. Sex Transm Infect 2010, 86(7):500-505.

8. Lan J, Walboomers JM, Roosendaal R, van Doornum GJ, MacLaren DM, Meijer CJ, van den Brule AJ: Direct detection and genotyping of Chlamydia trachomatis in cervical scrapes by using polymerase chain reaction and restriction fragment length polymorphism analysis. J Clin Microbiol 1993, 31:1060-1065

9. Lysén M, Osterlund A, Rubin CJ, Persson T, Persson I, Herrmann B: Characterization of ompA genotypes by sequence analysis of DNA from all detected cases of Chlamydia trachomatis infections during 1 year of contact tracing in a Swedish County. J Clin Microbiol 2004, 42:1641-1647.

10. Zheng HP, Jiang LF, Fang DY, Xue YH, Wu YA, Huang JM, Ou ZY: Application of an oligonucleotide array assay for rapid detecting and genotyping of Chlamydia trachomatis from urogenital specimens. Diagn Microbiol Infect Dis 2007, 57(1):1-6.

11. Gharsallah H, Frikha-Gargouri O, Besbes F, Sellami H, Znazen A, Hammami A: Development and application of an in house reverse hybridization method for Chlamydia trachomatis genotyping. J Appl Microbiol 2012, doi:10.1111/j.1365-2672.2012.05375.

12. Bébéar C, de Barbeyrac B: Genital Chlamydia trachomatis infections. Clin Microbiol Infect 2009, 15:4-10.

13. Gita S, Suneeta M, Anjana S, Niranjan N, Sujata M, Pandey RM: C. trachomatis in Female Reproductive Tract Infections and RFLP-Based Genotyping: A 16-Year Study from a Tertiary Care Hospital. Infect Dis Obstet Gynecol 2011, 2011:6. doi:10.1155/2011/548219. ID 548219.

14. Hsu MC, Tsai PY, Chen KT, Li LH, Chiang CC, Tsai JJ, Ke LY, Chen HY, Li SY: Genotyping of Chlamydia trachomatis from clinical specimens in Taiwan. J Med Microbiol 2006, 55:301-308.

15. Jurstrand $M$, Falk L, Fredlund $H$, Lindberg M, Olcén P, Andersson S, Persson K, Albert J, Bäckman A: Characterization of Chlamydia trachomatis omp1 
genotypes among sexually transmitted disease patients in Sweden. J Clin Microbiol 2001, 39:3915-3919.

16. Gao X, Chen XS, Yin YP, Zhong MY, Shi MQ, Wei WH, Chen Q, Peeling RW, Mabey D: Distribution study of Chlamydia trachomatis serovars among high-risk women in China performed using PCR-restriction fragment length polymorphism genotyping. J Clin Microbiol 2007, 45:1185-1189.

17. Lan J, Melgers I, Meijer CJ, Walboomers JM, Roosendaal R, Burger C, Bleker $\mathrm{OP}$, van den Brule AJ: Prevalence and serovar distribution of asymptomatic cervical Chlamydia trachomatis infections as determined by highly sensitive PCR. J Clin Microbiol 1995, 33:3194-3197.

18. Lima HE, Oliveira MB, Valente BG, Afonso DA, Darocha WD, Souza MC, Alvim TC, Barbosa-Stancioli EF, Noronha FS: Genotyping of Chlamydia trachomatis from endocervical specimens in Brazil. Sex Transm Dis 2007, 34:709-717.

19. Morré SA, Rozendaal $L$, van Valkengoed IG, Boeke AJ, van Voorst Vader PC, Schirm J, de Blok S, van Den Hoek JA, van Doornum GJ, Meijer CJ, van Den Brule AJ: Urogenital Chlamydia trachomatis Serovars in Men and Women with a Symptomatic or Asymptomatic Infection: an Association with Clinical Manifestations. J Clin Microbiol 2000, 38:2292-2296.

20. Petrovay F, Balla E, Nemeth I, Gonczol E: Genotyping of Chlamydia trachomatis from the endocervical specimens of high-risk women in Hungary. J Med Microbiol 2009, 58:760-764.

21. Sturm-Ramirez K, Brumblay H, Diop K, Guèye-Ndiaye A, Sankalé JL, Thior I, N'Doye I, Hsieh CC, Mboup S, Kanki PJ: Molecular epidemiology of genital Chlamydia trachomatis infection in high-risk women in Senegal, West Africa. J Clin Microbiol 2000, 38:138-145.

22. Molano M, Meijer CJLM, Morre SA, Pol R, van den Brule AJC: Combination of PCR Targeting the VD2 of omp1 and Reverse Line Blot Analysis for Typing of Urogenital Chlamydia trachomatis Serovars in Cervical Scrape Specimens. J Clin Microbiol 2004, 42:2935-2939.

23. Xiong L, Kong F, Zhou H, Gilbert GL: Use of PCR and Reverse Line Blot Hybridization Assay for Rapid Simultaneous Detection and Serovar Identification of Chlamydia trachomatis. J Clin Microbiol 2006, 44:1413-1418

24. Yamazaki T, Hagiwara T, Kishimoto T, Sasaki N, Takahashi S, Ishihara O, Wangroongsarb P, Kusum M, Sirivongrangsan P: Distribution of Chlamydia trachomatis serovars among female prostitutes and non-prostitutes in Thailand, and non-prostitutes in Japan during the mid-90s. Jpn J Infect Dis 2005, 58:211-213.

25. Ito $\mathrm{JI} \mathrm{Jr}$, Lyons JM, Airo-Brown LP: Variation in virulence among oculogenital serovars of Chlamydia trachomatis in experimental genital tract infection. Infect Immun 1990, 58(6):2021-3.

26. Jones RB, Williams JA, van der Pol B: Competetive growth of serovars $E$ and $\mathrm{F}$ combined in mixed tissue culture infections. In. Edited by Stephans Gl, Byrne Gl.; 1998:523-526.

27. Brunham RC, Kimani J, Bwayo J, Maitha G, Maclean I, Yang C, Shen C, Roman S, Nagelkerke NJ, Cheang M, Plummer FA: The epidemiology of Chlamydia trachomatis within a sexually transmitted diseases core group. J Infect Dis 1996, 173(4):950-6.

28. Dean D, Oudens E, Bolan G, Padian N, Schachter J: Major outer membrane protein variants of Chlamydia trachomatis are associated with severe upper genital tract infections and histopathology in San Francisco. J Infect Dis 1995, 172:1013-1022.

29. Quint KD, van Doorn LJ, Kleter B, de Koning MN, van den Munckhof HA, Morre SA, ter Harmsel B, Weiderpass E, Harbers G, Melchers WJ, Quint WG A highly sensitive, multiplex broad-spectrum PCR- DNA-enzyme immunoassay and reverse hybridization assay for rapid detection and identification of Chlamydia trachomatis serovars. J Mol Diagn 2007. 9:631-638.

30. Stevens MP, Twin J, Fairley CK, Donovan B, Tan SE, Yu J, Garland SM, Tabriz SN: Development and evaluation of an ompA quantitative real-time PCR assay for Chlamydia trachomatis serovar determination. J Clin Microbiol 2010, 48:2060-2065.

31. Suchland RJ, Stamm WE: Simplified microtiter cell culture method for rapid immunotyping of Chlamydia trachomatis. J Clin Microbiol 1991, 29(7):1333-8.

32. Caldwell HD, Wood H, Crane D, Bailey R, Jones RB, Mabey D, Maclean I, Mohammed Z, Peeling R, Roshick C, Schachter J, Solomon AW, Stamm WE, Suchland RJ, Taylor L, West SK, Quinn TC, Belland RJ, McClarty G: Polymorphisms in Chlamydia trachomatis tryptophan synthase genes differentiate between genital and ocular isolates. J Clin Invest 2003, 111(11):1757-69.

33. Dean D, Kandel RP, Adhikari HK, Hessel T: Multiple Chlamydiaceae species in trachoma: implications for disease pathogenesis and control. PLOS Med 2008, 5(1):e14

34. Ikehata M, Numazaki K, Chiba S: Analysis of Chlamydia trachomatis serovars in endocervical specimens derived from pregnant Japanese women. FEMS Immunol Med Microbiol 2000, 27:35-41.

35. Marangoni A, Foschi C, Nardini P, D’Antuono A, Banzola N, Di Francesco A, Ostanello F, Russo I, Donati M, Cevenini R: Chlamydia trachomatis serovar distribution and other sexually transmitted coinfections in subjects attending an STD outpatients clinic in Italy. New Microbiol 2012, 35:215-9.

36. Papadogeorgakis $\mathrm{H}$, Pittaras TE, Papaparaskevas J, Pitiriga V, Katsambas A Tsakris A: Chlamydia trachomatis serovar distribution and Neisseria gonorrhoeae coinfection in male patients with urethritis in Greece. J Clin Microbiol 2010, 48(6):2231-4.

37. Wang SP, Grayston JT: Immunologic relationship between genital TRIC, lymphogranuloma venereum, and related organisms in a new microtiter indirect immunofluorescence test. Am J Ophthalmol 1970, 70(3):367-74.

38. Bandea Cl, Debattista J, Joseph K, Igietseme J, Timms P, Black CM: Chlamydia trachomatis serovars among strains isolated from members of rural indigenous communities and urban populations in Australia. J Clin Microbiol 2008, 46(1):355-6

39. Beni BT, Motamedi H, Ardakani MR: Genotyping of the prevalent Chlamydia trachomatis strains involved in cervical infections in women in Ahvaz, Iran. J Med Microbiol 2010, 59:1023-1028.

40. Gallo Vaulet L, Entrocassi C, Corominas Al, Rodríguez Fermepin M: Distribution study of Chlamydia trachomatis genotypes in symptomatic patients in Buenos Aires, Argentina: association between genotype $\mathrm{E}$ and neonatal conjunctivitis. BMC Res Notes 2010, 9(3):34

41. De Jesús De Haro-Cruz M, Deleón-Rodriguez I, Escobedo-Guerra MR, LópezHurtado M, Arteaga-Troncoso G, Ortiz-Ibarra FJ, Guerra-Infante FM: Genotyping of Chlamydia trachomatis from endocervical specimens of infertile Mexican women. Enferm Infecc Microbiol Clin 2011, 29(2):102-8.

42. Donati M, Di Francesco A, D'Antuono A, Pignanelli S, Shurdhi A, Moroni A Baldelli R, Cevenini R: Chlamydia trachomatis serovar distribution and other concurrent sexually transmitted infections in heterosexual men with urethritis in Italy. Eur J Clin Microbiol Infect Dis 2009, 28(5):523-6.

doi:10.1186/1471-2334-12-333

Cite this article as: Gharsallah et al:: Chlamydia trachomatis genovar distribution in clinical urogenital specimens from Tunisian patients: high prevalence of $C$. trachomatis genovar $\mathrm{E}$ and mixed infections. $B M C$ Infectious Diseases 2012 12:333.

\section{Submit your next manuscript to BioMed Central and take full advantage of:}

- Convenient online submission

- Thorough peer review

- No space constraints or color figure charges

- Immediate publication on acceptance

- Inclusion in PubMed, CAS, Scopus and Google Scholar

- Research which is freely available for redistribution 